\title{
Multimodal Carriage of Goods by Sea: Time for an International Convention?
}

\author{
SIMON BAUGHEN
}

\section{Introduction}

Containerisation has profoundly changed the world of international maritime transport over the last 60 years. Goods stowed in a container can be carried by different modes of transport from the place where they are taken over by the carrier to the final place of destination, without being unpacked for sorting or verification when being transferred from one means of transport to another. In terms of value, global seaborne container trade is believed to account for approximately 60 per cent of all world seaborne trade, which was valued at around 12 trillion US dollars in 2017, with the quantity of goods carried by containers rising from around 102 million metric tons in 1980 to about 1.83 billion metric tons in $2017 .^{1}$

The computer on which I write this chapter will probably have originated in a factory in inland China. Its journey to me in Swansea will encompass varying modes of carriage performed under a single contract of carriage, crossing continents and crossing unimodal carriage conventions as it does so. From the factory in Wuhan in inland China, where it is packed into a container, it will be carried by road to Shanghai, where the container will be loaded onto a feeder vessel taking it to the great container hub in Singapore. There it will be loaded onto another vessel for the voyage to Marseilles. A bill of lading will be issued noting the reception of the container in apparent good order and condition and saying that it contains so many packages containing computers. ${ }^{2}$ At Marseilles it will be loaded onto a lorry, which will take it to Southampton via the ferry at Calais. At Southampton, the container will be unloaded from the lorry and stored at the terminal, to be picked up later by another lorry to take it to Swansea. This journey involves multiple legal regimes - domestic law applying to the first and final road legs and the feeder sea leg from China; the Hague-Visby Rules applying to the sea leg from Singapore; and the Convention on the Contract for the International Carriage of Goods by Road (Geneva, 19 May 1956) (CMR) ${ }^{3}$ applying to the road carriage, involving roll-on, roll-off at the ferry at Calais, from Marseilles to Southampton.

\footnotetext{
${ }^{1}$ Statista Research Department, 'Container Shipping - Statistics \& Facts', 10 October 2018; see www.statista.com/ topics/1367/container-shipping/.

${ }^{2}$ The effect of this clausing is that the statements as to what is inside the container will have no evidential effect, and in the event of damage or loss being apparent after final delivery of the container, it will be for the consignee to provide evidence as to the condition and quantity of the cargo loaded on board the vessel.

${ }^{3}$ See $n 29$ below.
} 
It is more than likely that my computer's journey, crossing continents and crossing legal regimes attaching to the different modes of performance, will be subject to a single contract of carriage from door to door. Seller and buyers - with containerised cargo it will almost always only be these two parties - and a financing bank, operating under a sale contract usually on Free on Board (FOB) or Free Carrier (FCA) terms, will generally prefer to deal with a single party who arranges for the transportation of goods and assumes contractual responsibility throughout. Enter the multimodal contract of carriage, contained in or evidenced by a multimodal bill of lading or sea waybill. The carrier under such contracts will undertake responsibility for the whole transport chain under one single transport contract. This contrasts with 'through transport,', in which a carrier accepts responsibility for only that part of the total movement performed with its own facilities, but also undertakes to arrange any additional leg acting as forwarding agent, on behalf of the shipper, in which capacity its duty is to select the on-carrier and other service providers with due care.

Although there are no internationally accepted definitions for the terms used in multimodal contracting, in most cases the terms are understood as follows. Multimodal transport (or combined transport or integrated transport) is where goods are delivered door to door, by a combination of at least two transport modes - eg road/rail/sea/air. It will involve a multimodal transport operator (MTO), who assumes contractual responsibility as a principal throughout, irrespective of whether it is also the party who actually performs the different stages of the transport. ${ }^{5}$ The MTO may actually perform only part of the carriage, such as the sea carriage, or may be a non-vessel-owning carrier (NVOC) and actually perform no part of the carriage. The MTO will issue a transport document, a multimodal transport bill of lading (MT Bill) or a sea waybill (MT Sea Waybill) to the shipper which covers the entire transport operation.

The MTO will also take, as cargo owner, separate bills or transport documents - such as a CMR consignment note - from its subcontracting carriers. If the cargo is lost, damaged or delayed, the cargo interests will sue the MTO in contract and the MTO will in turn exercise a right of redress against its negligent subcontractor(s) under its separate contract with them, to which the cargo interests will not be party. The MTO will also wish to protect itself from indemnity claims from its subcontractors in the event that the shipper or consignee brings a non-contractual action against them. This will be achieved by the inclusion in the multimodal transport document of the Himalaya and circular indemnity clauses that are ubiquitous in ocean bills of lading.

This means that two bills of lading or waybills will be issued: the multimodal bill of lading issued to the shipper by the multimodal carrier; and a bill of lading issued by the sea carrier to the multimodal carrier as shipper for the sea leg or the relevant transport document for the final inland leg by another means of transport. The first of these will be used under the contract of sale and any letter of credit opened to finance the sale. Those entitled to delivery of the cargo will obtain delivery at the place of delivery by presenting the multimodal bill to the actual carrier on the final leg. Delivery of cargo at the port of discharge which is carried under the sea carrier's

\footnotetext{
${ }^{4}$ Or 'intermodal transport', as it is referred to in the USA.

${ }^{5}$ The identity of 'the carrier' or the 'multimodal transport operator' will usually be expressly defined by the standard multimodal bill of lading forms. COMBICONBILL 1995 defines 'carrier' in $\mathrm{cl} 2$ as 'the party on whose behalf this bill of lading has been signed.' MULTIDOC 1995 defines multimodal transport operator in $\mathrm{cl} 2$ as 'the person named on the face hereof who concludes a Multimodal Transport Contract and assumes responsibility for the performance thereof as a carrier'.
} 
ocean bill will be through presentation of that bill by the shipper or consignee - the multimodal carrier. Problems may arise through the existence of two parallel bills of lading but can be averted by making out the second bill of lading to the order of the first carrier. ${ }^{6}$

There have so far been two attempts at a convention for multimodal carriage: the 1980 Geneva Convention on International Multimodal Transport of Goods (the 1980 MT Convention) and the 2008 United Nations Convention on Contracts for the International Carriage of Goods Wholly or Partly by Sea (the Rotterdam Rules). The former is dead in the water, and the latter is going that way, having obtained to date only four of the required 20 ratifications necessary for its coming into force. In this chapter I shall consider five problems presented by multimodal transport with a view to assessing whether there is a need for a new convention to regulate this form of international carriage of goods, or whether these problems are adequately resolved by the standard form contractual solutions that have been adopted, such as the two BIMCO bill of lading forms for multimodal carriage, COMBICONBILL and MULTIDOC.

\section{Five Problems with Multimodal Carriage of Goods}

Several potential problems can be identified with multimodal carriage of goods: whether a multimodal bill of lading can function as document of title; whether a third party can obtain title to sue under the contract of carriage contained in or evidenced by the multimodal bill of lading or waybill; whether the unimodal carriage conventions apply to the relevant international carriage elements of a multimodal contract; and, if so, the difficulties in applying the divergent provisions of the unimodal conventions to different segments of the multimodal contract.

\section{A. The Multimodal Bill of Lading as a Document of Title}

There is some uncertainty as to whether a multimodal bill of lading constitutes a document of title - a document whereby property ${ }^{7}$ in and possession ${ }^{8}$ of the goods represented by the bill can pass during the sea voyage by negotiation, without any attornment from the carrier. Such a bill will generally be a 'received for shipment' bill of lading. There is no clear authority as to whether such a bill of lading can constitute a document of title. Lloyd J, in The Lycaon, ${ }^{9}$ assumed that it could be such a document, relying on the decision of the Privy Council in The Marlborough Hill. ${ }^{10}$ However, the point in issue in that case was the definition of 'bill of lading' for the purposes of a statute conferring jurisdiction on the Admiralty Court. Diamond Alkali Export Corp v Bourgeois ${ }^{11}$ is claimed to be the authority for the contrary proposition that such bills cannot be documents

\footnotetext{
${ }^{6}$ Alternatively, the first carrier could release the second bill to the party holding the first carrier's bill on surrender by that party of the first carrier's bill of lading to the first carrier. That party would then present the second bill to obtain delivery. This is what happened in Carrington Slipways Pty Ltd v Patrick Operations Pty Ltd (The Cape Comorin) (1991) 24 NSWLR 745, where a freight forwarder issued a bill of lading to the shipper and then a second bill of lading was issued by a time charterer to the forwarder.

${ }^{7}$ Lickbarrow v Mason (1794) 5 TR 683, 101 ER 380.

${ }^{8}$ Meyerstein v Barber (1869-70) LR 4 HL 317.

${ }^{9}$ Elder Dempster Lines $v$ Zaki Ishag (The Lycaon) [1983] 2 Lloyd's Rep 548 (Com Ct).

${ }^{10}$ Owners of the Ship 'Marlborough Hill' v Alex Cowan \& Sons Ltd (The Marlborough Hill) [1921] 1 AC 444 (PC).

${ }^{11}$ Diamond Alkali Export Corp v Bourgeois [1921] 3 KB 443 (KB).
} 
of title. Again, the issue never directly arose in the case, which merely decided that these documents did not amount to good tender under a Cost, Insurance and Freight (CIF) sale, as they would not evidence the condition of the goods on shipment, when risk passed.

A received for shipment bill can be turned into a 'shipped' bill of lading by annotating it with the date of shipment. It will then be a shipped bill and will then certainly constitute a document of title. The fact that the bill of lading provides for delivery at an inland location will not prevent it being a document of title for the duration of the sea transit, ${ }^{12}$ although it may not continue to be a document of title for the final land transit. ${ }^{13}$

A further possible objection to a multimodal bill of lading amounting to a document of title is that it may well be issued by someone other than the actual sea carrier, such as a freight forwarder. In The Maheno, ${ }^{14}$ such a document was assumed not to be a document of title, although the actual decision proceeded on the basis that the forwarder had not contracted as the carrier. It has been doubted whether such a document can confer constructive possession in the goods to which it refers when the contractual carrier has never taken them into its physical possession. However, this objection applies equally to time charterers' bills of lading, which are clearly accepted as documents of title, and also to through bills of lading as regards the second sea leg. It is submitted that what matters is not the physical reception of the goods by the carrier, but its contractual capacity to control delivery by the performing carriers. This is borne out by the finding in Spectra International plc $v$ Hayesoak $L t d^{15}$ that a party could become a bailee of goods, even without taking physical possession of them, by obtaining a right to give directions to the warehouseman as to their delivery. Commercially, the contractual carrier does not actually need to be able to hand over the 'key to the warehouse'; it should be enough that he can direct the party who does have the key as to when it should be turned.

In practice, these uncertainties have not affected the widespread use of multimodal bills in international trade. Multimodal bills are acceptable documents for the purposes of Article 19 of UCP $600^{16}$ provided that they regulate all stages of the carriage, and it can be argued that this evidences a custom of merchants that a multimodal bill of lading constitutes a document of title. For CIF sales, there would be no problem with the tendering of a multimodal bill of lading, as it would satisfy the requirement of continuous contractual cover from receipt of the goods to their delivery. ${ }^{17}$

\footnotetext{
${ }^{12} \mathrm{G}$ Treitel and FMB Reynolds, Carver on Bills of Lading, 4th edn (London, Sweet \& Maxwell, 2017) para 8.087, citing Re Sutro \& Co v Heilbut, Symons \& Co [1917] 2 KB 348 (CA) and Johnson v Taylor Bros \& Co Ltd [1920] AC 144 (HL), although the point was not specifically addressed in either case.

${ }^{13}$ The custom found by the merchant jury in Lickbarrow $v$ Mason (n 7) was limited to 'anytime after such goods have been shipped, and before the voyage performed, for which they have been or are shipped'.

${ }^{14}$ The Maheno [1977] 1 Lloyd's Rep 81 (NZ SC). A similar assumption was made in Carrington Slipways (n 6).

${ }^{15}$ Spectra International plc v Hayesoak Ltd [1997] 1 Lloyd's Rep 153 (Central London County Ct). The point was raised before the Privy Council in Owners of Cargo Lately Laden on Board the KH Enterprise v Owners of the Pioneer Container (The Pioneer Container) [1994] 2 AC 324 (PC) in relation to the Scandutch claimants who had been issued with a bill of lading by an NVOC who had never taken possession of the cargo. Their Lordships did not think it right to allow the point to be raised for the first time before them, but Lord Goff observed (ibid 345): 'They wish to add however that, on the limited argument on this point which took place before them, it is difficult to see why the shipowners should not, when they received the goods of the Scandutch plaintiffs into their possession, have becomes responsible as bailees to the owners of the goods even if the goods were never in the possession of Scandutch.'

${ }^{16}$ ICC, Uniform Customs and Practice for Documentary Credits - UCP 600 (2007). This is subject to various conditions, principally that the MT Bill should: (i) indicate the name of the carrier and be signed appropriately; (ii) indicate that the goods have been 'dispatched, taken in charge or shipped on board at the place stated in the credit'; (iii) indicate the place so stated in the credit as well as the place of destination there stated; and (iv) contain or refer to conditions of carriage.

${ }^{17}$ Hansson $v$ Hamel \& Horley Ltd [1922] 2 AC 36 (HL).
} 


\section{B. Third Party Rights of Suit}

The multimodal bill will involve a shipper, who has made the contract of carriage with the MTO, and a consignee, who has not. But do multimodal bills of lading and sea waybills come within the ambit of the Carriage of Goods by Sea Act 1992 (COGSA 1992) so as to give rights of suit to the consignee?

This is an issue that previously received some academic commentary in relation to the applicability of the Bills of Lading Act 1855 to through bills, with Bateson and Carver arguing that such bills were not included within the Act. ${ }^{18}$ The joint report of the Law Commission and the Scottish Law Commission ${ }^{19}$ which led to the enactment of COGSA 1992 gives no real guidance on this issue. The report noted that traders typically treat such documents as traditional bills of lading and that provision is made for tender under the Uniform Customs and Practice for Documentary Credits, and reported that they had received 'no evidence from consultants that there are particular privity problems which are unique to combined transport bills of lading as distinct from the traditional ocean variety.' ${ }^{20}$ The report went on to state that 'since implementing legislation is expressed to cover any bill of lading, including "received for shipment" bills, multimodal documents are capable of falling within its ambit.' ${ }^{21}$

COGSA 1992 provides no definition of a 'bill of lading', although section 1(2)(b) provides that the Act applies to received for shipment bills. However, it is likely that this requires at least a designation of the carrying ship and of receipt by the sea carrier. Carver on Bills of Lading also argues that at common law a bill of lading refers only to a document containing or evidencing a contract for the carriage of goods by sea - a fact bolstered by the title of the Act itself, the 'Carriage of Goods by Sea Act 1992'.22 As against that, the definition of 'contract of carriage' in section 5(1) refers to the 'contract of carriage contained in or evidenced by' the bill of lading and makes no reference to that contract being by sea. If multimodal bills of lading do fall within COGSA 1992, the whole of the contract of carriage would be transferred, enabling the lawful holder to sue for loss or damage that occurred outside the period of sea carriage. ${ }^{23}$

In contrast, a 'sea waybill' is defined in section 1(3)(a) as 'such a receipt for goods as contains or evidences a contract for the carriage of goods by sea' (emphasis added), which would seem to exclude multimodal transport waybills from the scope of COGSA 1992. Against that is Quantum Corp Inc $v$ Plane Trucking $L t d,{ }^{24}$ in which the international road leg of a multimodal contract of carriage involving air carriage was held to be subject to CMR as involving 'carriage by road'. On this basis, the sea leg of a waybill could be regarded as constituting a contract for the carriage of goods by sea, as regards the sea carriage element of the overall carriage. If that is the case, and multimodal bills of lading are not to be treated as bills of lading under the Act, they could come back in under the provisions regarding sea waybills.

\footnotetext{
${ }^{18}$ HD Bateson, 'Through Bills of Lading' (1889) 5 LQR 424; TG Carver, 'On Some Defects in the Bills of Lading Act 1855' (1890) 6 LQR 289, 294.

${ }^{19}$ Law Commission and Scottish Law Commission, Rights of Suit in Respect of Carriage of Goods by Sea (Law Com No 196 and Scots Law Com No 130, 1991).

${ }^{20}$ ibid para 2.49 .

${ }^{21}$ ibid.

${ }^{22}$ Treitel and Reynolds, Carver on Bills of Lading (n 12) para 8.081.

${ }^{23}$ Alternatively, the Act might be construed so as to operate only as regards transfers of the contract of carriage that take place between shipment and completion of the sea voyage, during which period the document will be a document of title, provided there is a notation as to shipment.

${ }^{24}$ Quantum Corp Inc v Plane Trucking Ltd [2002] EWCA Civ 350, [2002] 1 WLR 2678.
} 
However, it should be noted that in no case has the validity of the operation of the Bills of Lading Act 1855, and latterly of COGSA 1992, been challenged in cases involving a multimodal contract of carriage by sea evidenced by a bill of lading or sea waybill. ${ }^{25}$ The most recent of these is The Maersk Tangier, ${ }^{26}$ where Andrew Baker J considered that the receiver had title to sue either as a party to the original contract or as the person to whom delivery was to be made under a waybill pursuant to section 2(1)(b) of COGSA 1992. The title to sue point was not considered in the subsequent decision of the Court of Appeal, which affirmed the first instance decision. ${ }^{27}$

One suspects that there is a convention among carriers and P\&I clubs not to take the point, but that does not mean that there is not a point to be taken. However, a simple way to enable the consignee to sue on the document would be by an assignment of rights by the shipper. If the multimodal bill falls outside COGSA 1992, then the shipper will have the right to claim damages for the consignee's loss, ${ }^{28}$ and that right can be assigned to the consignee.

\section{The Application of the Unimodal Conventions to the Various Modes of Carriage under a Multimodal Bill of Lading}

Multimodal carriage gives rise to the problem that one contract of carriage will often involve the application of two or more unimodal conventions. Apart from the three conventions for international sea carriage, there are unimodal conventions in force for international carriage of goods by road, rail, inland waterways and air. ${ }^{29}$ The conventions clearly apply to the contracts of carriage with the actual carrier, but what about the head contract for the multimodal carriage?

\section{(i) Sea Carriage}

The Hague and Hague-Visby Rules apply to cross-border sea carriage between convention countries on a 'tackle to tackle' basis. This period may exceptionally begin prior to the loading of the goods on to the sea vessel. In Volcafe Ltd $v$ Compania Sud Americana de Vapores $S A,{ }^{30}$ the sea carrier supplied the containers and loaded the cargo of coffee into them at an inland terminal. It was held that 'loading' under the Hague Rules commenced with the start of loading into the

\footnotetext{
${ }^{25}$ For other cases involving such carriage, where the validity of the operation of the legislation was not challenged, see eg Pyrene Co Ltd v Scindia Steam Navigation Co Ltd [1954] 2 QB 402 (QB); Mayhew Foods Ltd v Overseas Containers Ltd [1984] 1 Lloyd's Rep 317 (Com Ct).

${ }^{26}$ AP Moller-Maersk A/S (t/a Maersk Line) v Kyokuyo Ltd (The Maersk Tangier) [2017] EWHC 654 (Comm), [2017] 2 All ER (Comm) 922 [32]. Two of the three contracts of carriage involved onward land carriage from Yokohama to Shizimu. There was no problem with the Hague-Visby Rules applying to the sea leg of these contracts, contrary to dicta of Flaux J in Bhatia Shipping \& Agencies Pvt Ltd v Alcobex Metals Ltd [2004] EWHC 2323 (Comm), [2005] 2 Lloyd's Rep 336. Flaux J was one of the Court of Appeal judges in The Maersk Tangier [2018] EWCA Civ 778, [2018] 2 Lloyd's Rep 59.

${ }^{27}$ The Maersk Tangier (CA) (n 26).

${ }^{28}$ Under Dunlop v Lambert (1839) 6 Cl \& F 600, 7 ER 824.

${ }^{29}$ These are: Convention on the Contract for the International Carriage of Goods by Road (Geneva, 19 May 1956) (CMR); Appendix B to the Convention concerning International Carriage by Rail (COTIF) of 9 June 1999; Uniform Rules Concerning the Contract of International Carriage of Goods by Rail (CIM), applicable with effect from 1 July 2006 (COTIF/CIM); Budapest Convention on the Contract for the Carriage of Goods by Inland Waterways (Budapest, 3 October 2000) (CMNI); Convention for the Unification of Certain Rules Relating to International Carriage by Air (Warsaw, 12 October 1929) (Warsaw Convention); Convention for the Unification of Certain Rules for International Carriage by Air (Montreal, 28 May 1999) (Montreal Convention).

${ }^{30}$ Volcafe Ltd $v$ Compania Sud Americana de Vapores SA (t/a CSAV) [2016] EWCA Civ 1103, [2017] QB 915. The issue was not addressed in the subsequent decision of the Supreme Court ([2018] UKSC 61, [2019] AC 358), which reinstated the first instance decision on the burden of proof for the inherent vice exception in $\operatorname{Art} \operatorname{IV}(2)(\mathrm{m})$ of the Hague Rules.
} 
containers and that the rules would continue to apply to the contract of carriage during the road leg to the port and during warehousing at the port prior to actual loading onto the ship. ${ }^{31}$

Article I(b) of the Hague and Hague-Visby Rules provides that "Contract of carriage" applies only to contracts of carriage covered by a bill of lading or any similar document of title, insofar as such document relates to the carriage of goods by sea' (emphasis added). This has been interpreted as a clarification that the Hague and Hague-Visby Rules apply to sea legs of a multimodal transport operation covered by a multimodal bill and not as a prohibition of the application of the rules to multimodal carriage. ${ }^{32}$ A similar finding has been made in Australia in Parlux SpA $v M$ \& Imports Pty Ltd. ${ }^{33}$ This seems preferable to the brief dictum of Flaux J in Bhatia Shipping \& Agencies PVT Ltd $v$ Alcobex Metals Ltd, ${ }^{34}$ that '[s]ince the relevant contracts of carriage are MTDs, the Hague or Hague-Visby Rules and the 12-month time-limit under those Rules are of no application. ${ }^{35}$

The Hamburg Rules apply to cross-border sea carriage between convention countries on a 'port-to-port' basis. The position as regards the application of the Hamburg Rules to the sea carriage element of a multimodal contract is made clear by Article 1(6):

however, a contract which involves carriage by sea and also carriage by some other means is deemed to be a contract of carriage by sea for the purposes of this Convention only insofar as it relates to the carriage by sea.

\section{(ii) International Carriage by Road, by Inland Waterways and by Rail}

The scope of the application of these conventions is largely determined by the existence of an international contract of carriage of goods involving the relevant mode of transport, where the place of taking over of the goods and the place of delivery are in two different states, and one ${ }^{36}$ or both ${ }^{37}$ of those states are parties to the convention. CMR applies only to cross-border carriage by road, mainly in Europe. A carrier under CMR need not be an actual road carrier and can be an NVOC who is contracting as a carrier. ${ }^{38}$ Article 1(1) provides:

This Convention shall apply to every contract for the carriage of goods by road in vehicles for reward, when the place of taking over of the goods and the place designated for delivery, as specified in the contract, are situated in two different countries, of which at least one is a contracting country, irrespective of the place of residence and the nationality of the parties.

\footnotetext{
${ }^{31}$ The possibility of the parallel application of the Hague Rules and the CMR Convention was raised, but Flaux J in the Court of Appeal was of the view that such concerns were more apparent than real (Volcafe (CA) (n 30) [110]): 'The CMR Convention could not apply whilst the containers were being dressed and stuffed, since they were not at that stage on board a vehicle. Furthermore, the better view would seem to be that the CMR Convention ceases to apply as soon as "loading" within the Hague Rules begins: Clarke, International Carriage of Goods by Road, 6th edn (2014) pp 40-42.'

${ }^{32}$ See Pyrene $v$ Scindia (n 25) and Mayhew Foods (n 25) 320, where the Hague Rules and the Hague-Visby Rules, respectively, were held to apply to the sea carriage part of the contract of carriage.

${ }^{33}$ Parlux SpA v M \& U Imports Pty Ltd [2008] VSCA 161, (2008) 21 VR 170.

${ }^{34}$ Bhatia Shipping \& Agencies PVT Ltd v Alcobex Metals Ltd [2004] EWHC 2323 (Comm), [2005] 2 Lloyd's Rep 336 (QB).

${ }^{35}$ ibid [21]. The case involved a bill of lading which was subject to the provisions of the applicable law of the country where the loss or damage occurred. The bill of lading did not specifically incorporate the Hague or Hague-Visby Rules and the carriage was from India, which was not a Hague-Visby Rules country. The mandatory application of the Hague Rules to outward carriage from India under Indian law would be of no effect in a bill of lading subject to English law.

${ }^{36}$ In the case of CMR and CMNI.

${ }^{37}$ In the case of COTIF/CIM, the Warsaw Convention and the Montreal Convention.

${ }^{38}$ Aqualon (UK) Ltd $v$ Vallana Shipping Corp [1994] 1 Lloyd's Rep 669 (Com Ct); Ulster Swift Ltd v Taunton Meat Haulage Ltd [1977] 1 WLR 625 (CA).
} 
In the UK and in many other CMR countries, Article 1(1) has been interpreted as applying CMR to the international road leg of a multimodal contract for the carriage of goods falling within Article 1(1), whether before or after the carriage by the other mode of transport. This involves reading the words 'the place of taking over and the place designated for delivery, as specified in the contract' as referring to the places which the contract specifies for the taking over and delivery by the carrier in its capacity as international road carrier.

In Quantum Corp ${ }^{39}$ the Court of Appeal rejected the notion that a carriage involving different modes of transport could only fall within CMR if the carriage by road was the predominant mode. A cargo of hard disk drives was to be carried from Singapore to Dublin. The air carrier flew them to Paris on two airline pallets. From Paris, the pallets were to be carried by road to Dublin, on a roll-on, roll-off basis. The goods were stolen during a staged hijack while being carried by road in England. The question was whether the road carrier was subject to CMR or whether it could, instead, rely on the terms of a 'Himalaya' clause contained in the air waybill. The Court of Appeal held that, provided that carriage by road was permissible under the contract of carriage, CMR was capable of applying to the international road leg of a larger contract of carriage. In such circumstances, the places of taking over and delivery to which Article 1(1) referred had to be construed so as to refer to the start and end of the international road leg. CMR therefore governed that part of the contract which was to be performed by road: the journey from Paris to Dublin. ${ }^{40}$ A similar finding was made by the House of Lords in Datec Electronic Holdings Ltd $v$ United Parcels Service $L t d,{ }^{41}$ where domestic road carriage was followed by international air carriage, and then by international road carriage from Germany to Holland, which was held to be subject to CMR.

The Quantum Corp interpretation of Article 1(1) superimposes a 'virtual' contract for road carriage under CMR onto the overall multimodal contract. This may cause problems with regard to what constitutes 'delivery' for the purposes of the CMR time bar. Is it delivery under the 'virtual' contract, or under the multimodal contract? ${ }^{42}$ If the CMR 'virtual' contract is for the last stage of the multimodal contract, there may be a clash between the delivery obligations under the MT Bill, which requires presentation of the document, and the consignee's right to delivery and right to sue for loss under Article 13 of CMR. Are these given to the consignee/indorsee under the MT Bill, to the consignee named in the consignment note or to both parties?

A contrary interpretation of Article 1(1) has been reached by the courts in Germany and the Netherlands, which have held that CMR does not apply to multimodal carriage. ${ }^{43}$ This divergence in the European approach to the CMR and multimodal contracts means that the choice of law clause in the MT Bill becomes critical in identifying what regime applies to the international

\footnotetext{
${ }^{39}$ Quantum Corp (n 24).

${ }^{40} \mathrm{Had}$ the goods been unloaded from the trailer for the sea leg it is difficult to see how there could be any international element in the road carriage, in which case, CMR would not apply. The Court of Appeal refrained from commenting on this hypothesis.

${ }^{41}$ Datec Electronic Holdings Ltd $v$ United Parcels Service Ltd [2007] UKHL 23, [2007] 1 WLR 1325.

${ }^{42} \mathrm{M}$ Hoeks, Multimodal Transport Law: The Law Applicable to the Multimodal Contract for the Carriage of Goods (The Hague, Kluwer Law International, 2010) s 4.1.2.5.2 convincingly argues that it should be the latter, as the purpose of CMR, Art 32 is to determine that the limitation period starts only after the goods have been delivered to the consignee.

${ }^{43}$ BGH 17 July 2008, I ZR 181/05 (2009) European Transport Law 196 (Germany); Hoge Raad 1 June 2012, SS 2012, No 95 (Godafoss). Both decisions were made in the context of jurisdictional challenges as to whether the CMR jurisdiction provisions in Art 31 applied. Both countries have domestic laws for multimodal carriage when their national law is the law of the contract. In Belgium, the Cour de Cassation decided in TNT Express Belgium v Mitsui Sumitomo Insurance Co Europe Ltd (2006) European Transport Law 228 (Belgium) that CMR does apply to the international road leg of a multimodal contract of carriage, but only if the contractual agreement expressly provides for carriage by road or, where the contract leaves the means of transport open, if it can be inferred from the circumstances that the parties intended goods to be carried by road.
} 
road carriage element of the contract. A choice of German or Dutch law will displace CMR and will lead to the application, instead, of domestic German or Dutch law on multimodal carriage. The scope of application of CMNI and COTIF/CIM is framed in similar fashion to Article 1(1) of CMR. There is therefore the possibility of a similar divergence of interpretation as regards the application of these conventions to carriage by international waterways and rail carriage respectively, where this forms part of a multimodal contract of carriage.

The air conventions make it quite clear that they will operate as regards the international air carriage elements of a contract of carriage that involves performance by other modes of transport. For combined carriage, Article 38 of the Montreal Convention provides:

1. In the case of combined carriage performed partly by air and partly by any other mode of carriage, the provisions of this Convention shall, subject to paragraph 4 of Article 18, apply only to the carriage by air, provided that the carriage by air falls within the terms of Article 1 .

2. Nothing in this Convention shall prevent the parties in the case of combined carriage from inserting in the document of air carriage conditions relating to other modes of carriage, provided that the provisions of this Convention are observed as regards the carriage by air.

Article 31 of the Warsaw Convention is to similar effect.

\section{The Different Liability Regimes of the Unimodal Conventions}

The unimodal conventions currently in force exhibit a wide range of differences in their application, which leads to complexity when dealing with claims for localised loss or damage arising under a multimodal bill of lading. In this context, 'localised loss or damage' is where the loss or damage can be shown to have occurred during one stage of a multimodal carriage; by contrast, 'unlocalised loss or damage' is where the loss or damage occurs during the course of the multimodal carriage contract, but it cannot be shown to have occurred during any particular stage of that contract. The basic liability structure of all the conventions is one of presumed fault. If the loss or damage occurs during the carrier's period of responsibility, there is prima facie liability on the carrier, subject to their being able to prove that the loss was caused by the specified excepted perils. ${ }^{44}$ These excepted perils differ between conventions, but, except in the case of the Hague Rules, they amount to specific instances in which the loss or damage occurred without the fault of the carrier or its servants, agents and subcontractors. Under the Hague Rules, in contrast, there are two defences on which the carrier can rely which involve fault on the part of these parties the nautical fault exception in $\operatorname{Article} \operatorname{IV}(2)(a)$ and the fire exception in Article $\operatorname{IV}(2)(b)$. A further difference is that the Hague Rules do not provide for the carrier's liability as regards delay in the carriage.

The scope of the sea carriage conventions is tied to the documentation issued in respect of the carriage. For the Hague and Hague-Visby Rules, this is a bill of lading or similar document of title. ${ }^{45}$ The Hamburg Rules define contract of carriage as 'any contract whereby the

\footnotetext{
${ }^{44}$ eg CMR, Art 17(1): 'The carrier shall be liable for the total or partial loss of the goods and for damage thereto occurring between the time when he takes over the goods and the time of delivery, as well as for any delay in delivery.' This is not explicit in the Hague Rules, but it is implicit. In Volcafe (SC) (n 30) [20], Lord Sumption described the basic liability structure as follows: 'I consider that in principle where cargo was shipped in apparent good order and condition but is discharged damaged the carrier bears the burden of proving that that was not due to its breach of the obligation in article III rule 2 to take reasonable care.'

${ }^{45}$ This need not have been issued, but its issue must have been contemplated under the contract of carriage.
} 
carrier undertakes against payment of freight to carry goods by sea from one port to another ${ }^{46}$ but excludes its application as regards charter parties. ${ }^{47}$ The provisions defining the scope of the other unimodal conventions refer to specific documents, such as a consignment note under CMR and an air waybill under the Montreal Convention, but the conventions will still apply to the contract of carriage if that document is not used. ${ }^{48}$

There are major variations when it comes to limitation of liability. At the lower end of the scale there is sea carriage. Under the Hague Rules, the limits are $£ 100$ per package or unit, gold value, ${ }^{49}$ whilst under the Hague-Visby Rules they are 666.67 special drawing rights (SDR) per package or unit or 2 SDR per kg gross weight lost or damaged, whichever is the higher. ${ }^{50}$ Under the Hamburg Rules, the limits are 835 SDR per package or other shipping unit or 2.5 SDR gross weight of the goods lost or damaged, whichever is the higher. ${ }^{51} \mathrm{CMNI}$ adopts the Hague-Visby limits, but with special provisions for containers. ${ }^{52}$ The CMR limit is 8.33 SDR gross weight, ${ }^{53}$ while the highest terrestrial limit is under the COTIF/CIM for international rail carriage, with a limit of 17 SDR per kg of gross mass short. ${ }^{54}$ The highest limitation figure is that in the Montreal Convention, which provides an unbreakable limit of 19 SDR per $\mathrm{kg}$ for carriage of goods. ${ }^{55}$

Similar variation can be seen with regard to the time provided for bringing suit. For the sea carriage conventions, under both Hague and Hague-Visby Rules, suit must be commenced within one year from delivery or date when goods should have been delivered, failing which the claim is barred. ${ }^{56}$ Under the Hamburg Rules, the period is two years. ${ }^{57} \mathrm{CMR}$ provides a one year time limit, but three years in cases of wilful misconduct. ${ }^{58}$ The Montreal Convention and Warsaw Convention both have a two year time limit. ${ }^{59} \mathrm{CMNI}$ has a one year time limit. ${ }^{60} \mathrm{COTIF} / \mathrm{CIM}$ has a one year limit, ${ }^{61}$ but with a two year limit period in four specific instances. ${ }^{62}$

All of the conventions have a provision rendering null and void express provisions of the contract that derogate from the convention to the benefit of the carrier - such as Article III.8 of the Hague and Hague-Visby Rules, Article 26 of the Montreal Convention and Article 5 of

\footnotetext{
${ }^{46}$ Hamburg Rules, Art 1(6).

${ }^{47}$ ibid Art 2(3).

${ }^{48}$ eg CMR, Art 4: 'The contract of carriage shall be confirmed by the making out of a consignment note. The absence, irregularity or loss of the consignment note shall not affect the existence or the validity of the contract of carriage which shall remain subject the provisions of this Convention.'

${ }^{49}$ Hague Rules, Art IV(5).

${ }^{50}$ Hague-Visby Rules, Art IV(5)(a).

${ }^{51}$ Hamburg Rules, Art 6(1)(a).

${ }^{52}$ CMNI, Art 20(1): 'If the package or other loading unit is a container and if there is no mention in the transport document of any package or loading unit consolidated in the container, the amount of 666.67 [SDR] shall be replaced by the amount of 1,500 [SDR] for the container without the goods it contains and, in addition, the amount of 25,000 [SDR] for the goods which are in the container.'

${ }^{53} \mathrm{CMR}$, Art 23(3).

${ }^{54}$ COTIF/CIM, Art 30(2).

${ }^{55}$ Montreal Convention, Art 22(3). The figure under the Warsaw Convention, subject to the 1955 Hague Protocol, is 17 SDR per kg. This was also the figure under the Montreal Convention, Art 22(3), until it was raised at the end of 2009.

${ }^{56}$ Hague Rules, Art III(6); Hague-Visby Rules, Art III(6).

${ }^{57}$ Hamburg Rules, Art 20.

${ }^{58} \mathrm{CMR}$, Art 32(1).

${ }^{59}$ Montreal Convention, Art 35: Warsaw Convention, Art 29.

${ }^{60}$ CMNI, Art 24.

${ }^{61}$ COTIF/CIM, Art 48(1).

${ }^{62} \mathrm{ibid}$, providing a two-year period in cases of action: 'a) to recover a cash on delivery payment collected by the carrier from the consignee; $b$ ) to recover the proceeds of a sale effected by the carrier; $c$ ) for loss or damage resulting from an act or omission done with intent to cause such loss or damage, or recklessly and with knowledge that such loss or damage would probably result; $d$ ) based on one of the contracts of carriage prior to the reconsignment in the case provided for in Article 28'.
} 
COTIF/CIM. Under the Hamburg Rules, Article 23(1) renders null and void any stipulation which derogates directly or indirectly from the provisions of the convention, but Article 23(2) permits the carrier to increase his responsibilities and obligations under it. In contrast, Article 41(1) of CMR precludes any contractual derogation: 'any stipulation which would directly or indirectly derogate from the provisions of this Convention shall be null and void'. Similarly, under Article 25 of CMNI:

any contractual stipulation intended to exclude, limit or increase the liability, within the meaning of this Convention of the carrier, the actual carrier or their servants or agents, shift the burden of proof or reduce the periods for claims or limitations referred to in Articles 23 and 24 shall be null and void.

Most of the conventions contain a provision on third party rights - the right of the consignee to sue the carrier, as well as some form of Himalaya protection for third parties engaged by the carrier. CMR gives rights of suit to the consignee in respect of loss or delay, ${ }^{63}$ as do the Warsaw and Montreal Conventions, ${ }^{64}$ and COTIF/CIM. ${ }^{65}$ However, none of the sea conventions, nor CMNI, give rights of suit to third parties. All the conventions except the Hague Rules provide some form of protection to third parties engaged by the carrier to perform the contract. The Hague-Visby Rules, Article IV bis 2 extends the protection of the rules to servants and agents of the carrier but excludes independent contractors. There is a similar provision in the Hamburg Rules, Article 7(2), in favour of servants and agents of the carrier, or of the actual carrier, who can prove they acted within the scope of their employment, but without the exclusion of independent contractors; and also in CMNI, Article 17(3), and in the Montreal Convention, Article 30. Wider protection to third parties is provided by CMR, Article 28(2):

In cases where the extra-contractual liability for loss, damage or delay of one of the persons for whom the carrier is responsible under the terms of Article 3 is in issue, ${ }^{66}$ such person may also avail himself of the provisions of this Convention which exclude the liability of the carrier or which fix or limit the compensation due.

Similarly, COTIF/CIM, Article 40, extends its provisions to 'other persons whose services he makes use of for the performance of the carriage, when these servants and other persons are acting within the scope of their functions' and to 'servants or other persons for whom the carrier is liable pursuant to Article 40'.

Rules on jurisdiction appear in Article 21 of the Hamburg Rules, Article 32 of CMR, Article 46 of COTIF/CIM, Article 28 of the Warsaw Convention and Article 33 of the Montreal Convention, ${ }^{67}$ but not in the Hague and Hague-Visby Rules, nor in CMNI (which contains provisions on applicable law in Article 29).

\footnotetext{
${ }^{63} \mathrm{CMR}$, Art 13(1). This article does not refer to a claim in respect of damage, but Continental case law is to the effect that this is within Art 13. See, eg OLG Karlsruhe, 24 May 1967 (1967) ULC 289; RB Antwerpen, 7 December 1973 (1976) 11 ETL 295; App Bruxelles, 30 October 1975 (1976) 11 ETL 238.

${ }^{64}$ Warsaw Convention, Arts 13(3) and 30(3); Montreal Convention, Arts 13(3) and 36(3).

${ }^{65}$ COTIF/CIM, Art 44 gives the consignee the right to 'bring an action based on the contract of carriage ... from the time when he has 1 . taken possession of the consignment note, 2. accepted the goods, or 3. asserted his rights pursuant to Article $17 \$ 3$ or Article $18 \$ 3$ '.

${ }^{66}$ See further CMR, Art 3: 'agents and servants and of any other persons of whose services he makes use for the performance of the carriage, when such agents, servants or other persons are acting within the scope of their employment'.

${ }^{67}$ These rules will take precedence over those in the Recast Brussels Regulation (Regulation (EU) 1215/2012 of the European Parliament and of the Council of 12 December 2012 on jurisdiction and the recognition and enforcement of judgments in civil and commercial matters [2012] OJ L351/1). This follows from Art 71 of the Regulation, which determines that the Regulation 'shall not affect any conventions to which the Member States are parties and which in relation to particular matters, govern jurisdiction or the recognition or enforcement of judgment'.
} 


\section{E. Multimodal Operation of the Unimodal Conventions}

A further complication in the multimodal jigsaw is that some of the unimodal conventions make provision for limited application of their terms to other modes of carriage. Article 2(1) of CMR deals with 'roll-on, roll-off' road carriage over another mode of transport and applies the convention to the whole of the carriage. This is subject to a proviso that applies if the damage, loss or delay in delivery of the goods occurred during the other mode of carriage due to fault of the road carrier or by an event that could not have occurred solely in the course of and by reason of the other mode of carriage. In this event, CMR may be displaced and, instead, the carrier's liability will be determined

in the manner in which the liability of the carrier by the other means of transport would have been determined if a contract for the carriage the goods alone had been made by the sender with the carrier by the other means of transport in accordance with the conditions prescribed by law for the carriage of goods by that means of transport.

This requires the court to construct a hypothetical contract between the sender and the carrier by the other means of transport and then to determine whether or not there would be conditions prescribed by law applicable to that contract. Absent such prescribed conditions, CMR will continue to govern the liability of the carrier by road. ${ }^{68}$

This complex CMR provision - described as 'the English nightmare' because it was inserted at the insistence of English ferry companies - leads to a complex search for the terms of this hypothetical contract that would have been concluded for the carriage by the other means of transport. In Thermo Engineers Ltd $v$ Ferrymasters $L t d,{ }^{69}$ maritime-specific damage occurred when a steam heat exchanger on a trailer hit the deckhead of the vessel while the trailer was being loaded onto the vessel. Neill J held that it would not be automatic that the carrier's liability would be on the terms of the Hague-Visby Rules, given that Article V allows the parties to reduce the shipowner's defences and increase its obligations. Another possibility, which was not considered by Neill J, was that the ocean carrier concerned may only have been prepared to contract on the basis that a waybill was issued. As the Hague-Visby Rules do not mandatorily apply to waybills, liability would, in the absence of 'such prescribed conditions', continue to be governed by CMR.

The CMNI's multimodal aspect is found in Article 2(2), which provides: 'This Convention is applicable if the purpose of the contract of carriage is the carriage of goods, without transshipment, both on inland waterways and in waters to which maritime regulations apply'. CMNI will not apply where there is transshipment, nor where (i) a maritime bill of lading has been issued in accordance with the maritime law applicable ${ }^{70}$ or (ii) the distance to be travelled in waters to which maritime regulations apply is the greater. This effectively rules out a conflict with the Hague Rules, which apply to bills of lading for international carriage, and so would be classed as 'maritime' bills of lading under CMNI.

\footnotetext{
${ }^{68} \mathrm{CMR}$, Art 2(1): 'the liability of the carrier by road shall be determined not by this convention but in the manner in which the liability of the carrier by the other means of transport would have been determined if a contract for the carriage [of] the goods alone had been made by the sender with the carrier by the other means of transport in accordance with the conditions prescribed by law for the carriage of goods by that means of transport'.

${ }^{69}$ Thermo Engineers Ltd $v$ Ferrymasters Ltd [1981] 1 WLR 1470 (QB).

${ }^{70}$ Whatever a 'maritime' bill may mean.
} 
COTIF/CIM may expand into other modes of transport through Article 1(3), where there is internal carriage by road or inland waterway in a Member State as a supplement to transfrontier carriage by rail. Article 1(4) provides:

When international carriage being the subject of a single contract of carriage includes carriage by sea or transfrontier carriage by inland waterway as a supplement to carriage by rail, these Uniform Rules shall apply if the carriage by sea or inland waterway is performed on services included in the list of services provided for in Article $24 \$ 1$ of the Convention. ${ }^{71}$

The Warsaw and Montreal Conventions are meanwhile clear as to their unimodal effect. Article 18(1) of the Montreal Convention provides:

The carrier is liable for damage sustained in the event of the destruction or loss of or damage to, cargo upon condition only that the event which caused the damage so sustained took place during the carriage by air.

Similarly, Article 18(1) of the Warsaw Convention provides:

The carrier is liable for damage sustained in the event of the destruction or loss of, or of damage to, any registered luggage or any goods, if the occurrence which caused the damage so sustained took place during the carriage by air.

Carriage by air is defined in Article 18(3) of the Montreal Convention as comprising 'the period during which the cargo is in the charge of the carrier. The equivalent provision in the Warsaw Convention, Article 18(2), contains the additional words 'whether in an aerodrome or on board an aircraft, or, in the case of a landing outside an aerodrome, in any place whatsoever'. It is likely that the omission of these words extends the scope of the Montreal Convention to the functional limits of the airport - to any airport-related area outside the airport perimeter.

A limited multimodal scope is provided by Article 18(3) of the Warsaw Convention and Article 18(4) of the Montreal Convention. Each states that the period of the carriage by air does not extend to any carriage by land, by sea or by inland waterway performed outside an airport, but goes on to provide that:

If, however, such carriage takes place in the performance of a contract for carriage by air, for the purpose of loading, delivery or trans-shipment, any damage is presumed, subject to proof to the contrary, to have been the result of an event which took place during the carriage by air.

The operation of the convention outside the airport requires that: (i) the non-aerial segment is covered by a contract for carriage by air; (ii) the non-aerial segment is performed with the aim of delivering the goods to the consignee, loading them on an aircraft or transshipping them; and (iii) the event causing the loss, damage or delay cannot be identified as occurring during either the aerial segment or the non-aerial segment of the carriage. Notwithstanding this, there has been a

\footnotetext{
${ }^{71}$ In this event, COTIF/CIM, Art 38 allows a Member State, by requesting that a suitable note be included in the list of service to which these Uniform Rules apply, to add four additional grounds of exemption from liability to those provided for in Art 23: (i) fire, if the carrier proves that it was not caused by his act or default, or that of the master, a mariner, the pilot or the carrier's servants; (ii) saving or attempting to save life or property at sea; (iii) loading of goods on the deck of the ship, if they are so loaded with the consent of the consignor given on the consignment note and are not in wagons; and (iv) perils, dangers and accidents of the sea or other navigable waters. Reliance on these additional maritime perils is subject to proof by the carrier that the loss, damage or exceeding the transit period occurred between loading onto and unloading from the ship. The carrier will nevertheless remain liable if the person entitled proves that the loss, damage or exceeding the transit period is due to the fault of the carrier, the master, a mariner, the pilot or the carrier's servants.
} 
trend in some US courts to give a door-to-door application of the two air conventions to carriage covered by a door-to-door air waybill. ${ }^{72}$ There is a further extension to non-aerial carriage under Article 18(4) of the Montreal Convention in cases of unauthorised substitution by the carrier of the intended air carriage by another mode of transport.

\section{Solutions to the Problems}

\section{A. International Conventions}

Multimodal transport gives rise to the problem that one contract of carriage will involve the application of two or more unimodal conventions. There are three ways in which this problem can be addressed either by a dedicated multimodal convention or by mandatory national law. First, the multimodal contract could be subject to a uniform system of liability. This will involve a clash with the unimodal conventions which could be avoided if liability, limitation and time bar provisions were as good for the shipper as those in the most generous of those conventions. Secondly, a network system could be applied where a default regime is applied for the multimodal carriage, which in the case of localised loss or damage gives way to the provisions of mandatory unimodal conventions or mandatory national laws governing the particular stage at which the loss or damage occurred. Thirdly, a modified network system could be applied where a uniform liability regime applies, but limitation of liability defers to the provisions of the unimodal convention or mandatory national law that applies to the stage of the carriage at which the loss or damage took place.

Two conventions have attempted to address the problems associated with the clash of conventions involved in multimodal transport.

The first was the 1980 MT Convention, which applied a uniform liability system for both localised and non-localised loss occurring while the MTO is in charge of the goods, based on the principle of 'presumed fault or neglect' - a regime similar to that of the Hamburg Rules. Article 16(1) provided a defence if the multimodal transport operator could prove that 'he, his servants or agents or any other person referred to in Article 15 took all measures that could reasonably be required to avoid the occurrence and its consequences'. This was subject to Article 4(1), which provided that: 'This Convention shall not affect, or be incompatible with, the application of any international convention or national law relating to the regulation and control of transport operations.'

Limitation of liability was dealt with under a network system, under which there would be a liability regime under the convention and a separate regime for localised loss - the limits of any unimodal convention or mandatory law applying to that stage of the carriage would apply instead if their limitation figure was higher than those provided by the convention. The convention's limits were 920 SDR per package or other shipping unit or 2.75 SDR per kg of gross weight of the goods lost or damaged, whichever is the higher, where the multimodal transport, according to the contract, included carriage by sea or by inland waterway. If this was not the case, the CMR level of 8.33 SDR per kg of gross weight of the goods lost or damaged applied.

\footnotetext{
${ }^{72}$ See G Leloudas, 'Door to Door Application of the International Air Law Conventions: Commercially Convenient but Doctrinally Dubious' [2015] Lloyd's Maritime and Commercial Law Quarterly 368. CMR rules out such expansion in Europe.
} 
The MT Convention failed to attract sufficient ratifications to enter into force. This was due to three reasons: (i) the basis of liability, which was modelled after the Hamburg Rules, rather than the Hague-Visby Rules; (ii) the monetary limitation of liability, which some considered as too high; and (iii) the principle of uniform liability, which some considered to raise concerns both in relation to recourse actions by an MTO against a subcontracting unimodal carrier and for introducing mandatory liability levels in relation to transports otherwise not subject to mandatory law, such as road and rail transport not covered by CMR or CIM/COTIF. However, the MT Convention has been influential on the contractual rules which have been developed for multimodal carriage.

The second convention is the Rotterdam Rules - a 'maritime plus' convention, applying to international door-to-door carriage involving international sea carriage. The Rotterdam Rules provide a 50 per cent uplift on the Hague-Visby limits - 3 SDR per kg or a 875 SDR package or shipping unit, whichever is the higher - and doubled the time for bringing suit or commencing arbitration. As well as carriers, certain of their subcontractors who constituted 'maritime performing parties' are brought directly within scope of the convention. Article 57 makes some provision for creating third party rights of suit under bills of lading (or 'negotiable transport documents'), although commentators are divided as to whether those rights extend beyond the right to delivery under chapter 9 of the Rotterdam Rules and the right of control under chapter 10.

The potential clash with the non-maritime transport conventions is addressed, not entirely successfully, through two articles. Article 26 provides a network solution to the problems of competing conventions that occur with multimodal carriage. Where the loss, damage or event causing delay occurs during the carrier's period of responsibility, provisions of another international 'instrument' will prevail over the convention, but only to the extent that they: (i) relate to the carrier's liability, limitation of liability and time for suit; (ii) cannot be departed from to the shipper's detriment under the terms of the other 'instrument'; and (iii) would have applied to a hypothetical contract between the shipper and the carrier for the particular stage of carriage where the loss, damage or event causing delay occurred. Thus, provisions of the convention relating to the right of control and the right to delivery will still prevail over those in the other 'instrument', and will also prevail where the claimant is unable to prove where during the carriage the loss occurred. Article 82 defers to the air, road, rail and inland waterway conventions as regards their multimodal provisions. Eleven years on, the Rotterdam Rules seem to be going the same way as the MT Convention - they have attracted only four of the 20 ratifications necessary for their coming into force.

Accordingly, there is currently no international instrument in force that deals with multimodal transport, although there are various regional agreements ${ }^{73}$ and national laws, such as those in Germany and the Netherlands, ${ }^{74}$ regulating such carriage.

\section{B. Contractual Solutions}

Although the 1980 MT Convention never entered into force, a modified version of its provisions was to provide the basis for the UNCTAD/ICC Rules for Multimodal Transport Documents,

\footnotetext{
${ }^{73}$ eg Asociacion Latinoamericana de Intergracion [Latin American Integration Association, ALADI] Agreement on International Multimodal Transport, 8 November 1996.

${ }^{74}$ See $\mathrm{n} 43$ above.
} 
which entered into force on 1 January 1992. These are incorporated in widely used multimodal transport documents, such as the FIATA FBL 1992 and MULTIDOC 95. They are of a purely contractual nature and apply only if they are incorporated into a contract of carriage, without any formal requirement for 'writing. ${ }^{75}$ They prevail over any inconsistent terms in the multimodal bill of lading, ${ }^{76}$ but can only take effect to the extent that they are not contrary to the mandatory provisions of international conventions or national law applicable to the multimodal transport contract. ${ }^{77}$

The UNCTAD/ICC Rules are based on the MT Convention with the same basis of liability and the same defence available to the MT carrier. ${ }^{78}$ They differ from the MT Convention as follows. For there to be liability for delay in delivery, they require the consignor to make a declaration of interest in timely delivery, which must also be accepted by the MTO. ${ }^{79}$ In cases of sea carriage or by inland waterways, the UNCTAD/ICC Rules provide two additional defences - the nautical fault and fire exceptions in $\operatorname{Article} \operatorname{IV}(2)(a)$ and (b) of the Hague Rules, subject to the overriding requirement of the proof of exercise of due diligence to provide a seaworthy vessel..$^{80}$ The basic limitation figure is the Hague-Visby limitation of 666.67 SDR per package or unit, with its container formula, or the weight alternative of 2 SDR per kg, rather than the higher 2.75 SDR limit in the MT Convention. ${ }^{81}$ If there is no carriage by sea or inland waterways, the limit is the CMR limit of 8.33 SDR per kg. ${ }^{82}$ Liability for delay in delivery or consequential loss is limited to an amount not exceeding the equivalent of the freight charged under the multimodal transport contract, with an aggregation of the limits so that they do not exceed the limit of liability for total loss of the goods. ${ }^{83}$

With localised loss, these limits give way to those provided in an applicable international convention or mandatory national law which would have provided another limit of liability - and not necessarily a higher limit as provided by the MT Convention - if a separate contract had been made for that particular stage of transport. However, as well as limitation, the liability rules of any unimodal convention applicable to the stage at which the loss or damage can be shown to have occurred will prevail over those in the document, both through the mandatory operation of the convention in question and through Rule 13 of the UNCTAD/ICC Rules. The rules provide for a nine month time limit for bringing claims, so as to give the MT carrier time to bring recourse actions against its subcontractors. However, this will be displaced by the time bar provisions in any mandatory international convention or national law governing the stage of transport during which the loss damage or delay occurred.

BIMCO have produced two contractual forms for multimodal bills of lading - MULTIDOC and COMBICONBILL - both of which are available in bill of lading and waybill formats. Both forms adopt the presumed fault liability scheme of the MT Convention. MULTIDOC provides that the MTO shall be responsible for the acts and omissions of his servants or agents when any such servant or agent is acting within the scope of his employment, or of any other person of whose services he makes use for the performance of the contract as if such acts and omissions

\footnotetext{
${ }^{75}$ UNCTAD/ICC Rules for Multimodal Transport Documents, r 1.1.

${ }^{76}$ ibid $r 1.2$.

77 ibid $r 13$.

${ }^{78} \mathrm{ibid}$ r 5.1: the MTO's liability is subject to a qualification where 'the MTO proves that no fault or neglect of his own, his servants or agents or any other person referred to in Rule 4 has caused or contributed to the loss, damage or delay in delivery'.

${ }^{79}$ ibid r 5.1.

${ }^{80}$ ibid r 5.4 .

${ }^{81}$ ibid r 6.1.

82 ibid r 6.3.

${ }^{83}$ ibid rr 6.5, 6.6.
} 
were his own. There is a similar provision in COMBICONBILL as regards the responsibility of the carrier. Both spell out the common law delivery obligations of the carrier when in bill of lading format. The significant difference between the forms is the reference to liability for delay under MULTIDOC - this may make it unacceptable to P\&I clubs, which require terms of carriage to be on a Hague/Hague-Visby basis, which does not provide for liability for delay. ${ }^{84}$

Under MULTIDOC, ${ }^{85}$ the front of the bill incorporates the UNCTAD/ICC Rules. It therefore brings in the additional defences for carriage by sea or by inland waterway, adding in the HagueVisby defences found in Article IV(2)(c)-(p), but not (q), subject to requirement of the proof of exercise of due diligence to provide a seaworthy vessel. ${ }^{86}$ For limitation of liability, MULTIDOC adopts the twofold sea and road scheme of the UNCTAD/ICC Rules, together with the limitation for delay claims, subject to a limit of $\$ 500$ per package or customary freight unit where US Carriage of Goods by Sea Act 1936 (COGSA 1936) applies.

Under COMBICONBILL, ${ }^{87}$ which can be used for either port-to-port or multimodal carriage, the carrier is liable for loss or damage to the goods occurring between the time when it receives the goods into its charge and the time of delivery. Eight specific defences are provided, based on the defences specified in CMR Article 17(2), some of the special defences specified in CMR Article 17(4) and the Hague Rules strike clause found in Article IV(2)(j). These eight defences are: (i) the wrongful act or neglect of the merchant; (ii) compliance with the instructions of the person entitled to give them; (iii) the lack of, or defective conditions of, packing in the case of goods which, by their nature, are liable to wastage or to be damaged when not packed or when not properly packed; (iv) handling, loading, stowage or unloading of the goods by or on behalf of the merchant; (v) inherent vice of the goods; (vi) insufficiency or inadequacy of marks or numbers on the goods, covering or unit loads; (vii) strikes, lock-outs, stoppages or restraints of labour from whatever cause, whether partial or general; and (viii) any cause or event which the carrier could not avoid and the consequence whereof he could not prevent by the exercise of reasonable diligence. ${ }^{88}$ The basic limitation figure is the Hague-Visby weight alternative of 2 SDR per kg gross weight goods lost or damaged, but with no package limitation, ${ }^{89}$ as well as the UNCTAD/ICC Rules limitation for delay claims if the carrier is held liable for delay.

The basic liability regime is displaced in cases of localised loss or damage - in which case the merchant is entitled to have liability determined in accordance with the mandatory international convention regime or national law applicable to that leg of the carriage. ${ }^{90}$ For localised loss during

\footnotetext{
${ }^{84}$ The carrier will still be liable for delay, but this will be under national law, and the carrier will have complete freedom of contract to limit or exclude this liability. See S Ciger, 'Claims for Compensation for Delay in Delivery and Notice Requirements under Article 23.4 of the Rotterdam Rules' (2015) 21 Journal of International Maritime Law 39.

${ }^{85} \mathrm{cl} 19$.

${ }^{86} \mathrm{cl} 11$.

${ }^{87}$ COMBICONBILL, cl 9.

${ }^{88}$ For defences (iii)-(vii), a formula applies which is similar to that adopted in Art 18(2) of CMR, for the special risks defences in Art 17(2). If the carrier establishes that the loss or damage could be attributed to one or more of the causes or events, it shall be presumed that it was so caused, with the merchant being entitled to prove that the loss or damage was not, in fact, caused either wholly or partially by one or more of the causes or events.

${ }^{89}$ BIMCO's explanatory notes justify this omission by reference to the carrier's position in recourse actions against its subcontractors, noting 'At the same time, since haulers only accept liability on the basis of weight limitation, it was agreed to make no reference to the package limitation'.

${ }^{90}$ The Unfair Contract Terms Act 1977 is one such national law. In Granville Oil \& Chemicals Ltd v Davis Turner \& Co Ltd [2003] EWCA Civ 570, [2003] 2 Lloyd's Rep 356, the nine-month time limit in such a contract was held to be 'reasonable'. The 1977 Act will not cover a contract for the carriage of goods by ship, but will cover a multimodal carriage contract, involving sea and road carriage, even when the damage took place during the sea leg. Compare this approach to classification with that of the Court of Appeal in Quantum (n 24). It should be noted that the Hague-Visby Rules did not apply, as carriage was from Kuwait, which is not a party to the Rules. Had the Hague-Visby Rules applied, the nine-month limit would have been struck out by Art III(8).
} 
carriage by sea or inland waterways that is not subject to a mandatory national law or international convention, ${ }^{91}$ the Hague-Visby Rules apply to all goods, whether carried on deck or not. Their application is contractual, ${ }^{92}$ and as such their provisions are therefore displaced by other specific provisions in the bill, such as the nine month time limit.

Clause 5 of both forms - MULTIDOC and COMBICONBILL - provide for disputes to be determined by the courts of the place where the MTO has its principal place of business and to be governed by the law of that place. This harmonises with those unimodal conventions that have jurisdiction provisions, as this place of jurisdiction constitutes one of the permitted places in all such conventions. Both forms of bill also protect the carrier's servants, agents and subcontractors by a combined circular indemnity and Himalaya clause. ${ }^{93}$ In the 2016 version of the forms, a total exemption is given to a wide category of performing parties engaged or employed by the carrier. ${ }^{94}$ The total exemption granted by the clause is likely to be struck out by the non-derogation provisions of the applicable unimodal convention covering the stage at which the loss, damage or delay occurred. This is certainly the case with the Hague Rules as regards the shipowner as a subcontractor under a charterer's bill, ${ }^{95}$ although not as regards non-carrier subcontractors. ${ }^{96}$ The Himalaya clause provides for the right of 'servants' to enforce all carrier's rights and exemptions, including the right to enforce any jurisdiction or arbitration clause. ${ }^{97}$

The MULTIDOC and COMBICONBILL forms, or variants of them, are in widespread use, but other contractual forms also exist. Some multimodal bills will extend the provisions of a unimodal convention to the entire multimodal contract of carriage, or to parts of it that would fall outside its ambit. ${ }^{98}$ In the USA, multimodal bills incorporating COGSA 1936 to the entire carriage have been held to cover inter-state rail carriage within the USA to the place of delivery, notwithstanding domestic legislation on such carriage (the 'Carmack Amendment'). ${ }^{99}$ If this results in a clash with the mandatory provisions of another unimodal convention, such incorporation will be rendered nugatory by any non-derogation provisions. ${ }^{100}$ The current International

\footnotetext{
${ }^{91}$ COMBICONBILL, cl 11(2).

${ }^{92}$ If it is argued that an MT Bill is not a bill of lading or similar document of title, the rules would apply contractually as under a clause paramount in a charter with the necessary manipulation to references to 'bill of lading.

${ }^{93}$ COMBICONBILL, cl 15; MULTIDOC, $\mathrm{cl} 14$.

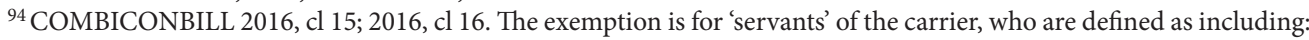
'the owners, managers, and operators of vessels (other than the Carrier); underlying carriers; stevedores and terminal operators; and any direct or indirect servant, agent, or subcontractor (including their own subcontractors), or any other party employed by or on behalf of the Carrier, or whose services or equipment have been used to perform this contract whether in direct contractual privity with the Carrier or not.'

${ }^{95}$ Homburg Houtimport BV v Agrosin Private Ltd (The Starsin) [2003] UKHL 12, [2004] AC 715.

${ }^{96}$ Whitesea Shipping \& Trading Corp v El Paso Rio Clara Ltda (The Marielle Bolten) [2009] EWHC 2552 (Comm), [2010] 1 Lloyd's Rep 648.

${ }^{97}$ Thereby getting around the Privy Council's decision in The Mahkutai [1996] AC 650 (PC).

${ }^{98}$ Princes Buitoni Ltd v Hapag-Lloyd AG [1991] 2 Lloyd's Rep 383 (CA). CMR applied contractually to the land leg of a multimodal bill of lading, even though there was no international carriage by road as required by CMR.

${ }_{99} 49$ USC 11707 (1979). See Kawasaki Kisen Kaisha $v$ Regal-Beloit Corp 561 US 89 (2010).

${ }^{100}$ Unless suit is brought in a country which is not a party to the unimodal convention, such as the USA, for the other mode of transport. In Hartford Fire Insurance Co v Orient Overseas Container Line (The OOCL Bravery) [2000] AMC 1305, [2000] 1 Lloyd's Rep 394 (SDNY) the limits in COGSA 1936, which were contractually applied to the entire multimodal carriage, were applied, rather than the lower CMR limits, which would have covered the international road carriage in Europe during which the goods were stolen. On appeal, the Second Circuit held that CMR applied due to the floating choice of law clause, which provided that 'each stage of the transport shall be governed according to any law and tariffs applicable to such stage. The District Court had not enforced this clause, incorrectly applying COGSA ex proprio vigore, whereas this would only be the case during 'the period from the time when the goods are loaded on to the time when they are discharged from the ship?
} 
Air Transport Association (IATA) air waybill applies the Montreal Convention limits to the entire carriage, ${ }^{101}$ but does not extend either the Warsaw Convention or the Montreal Convention to the non-aerial parts of the carriage. ${ }^{102}$

\section{Conclusion}

The liability regime for multimodal carriage is undeniably complex and untidy. Apart from the differences between the applicable unimodal conventions, there are various gaps in the patchwork of unimodal conventions and domestic laws that govern the performance of this single multimodal contract of carriage in its different modes of performance. What regime governs storage between modes? What regime governs where there is progressive damage to the goods in the container across modes? Is the time limit under the contract dependent on the mode in which the loss, damage or delay occurred? If so, is the starting point of 'delivery' under that mode or is it delivery at the end of the overall contractual carriage? ${ }^{103}$

What should be done about this maddeningly messy patchwork of overlapping unimodal conventions and national laws? One solution would be a dedicated multimodal convention just for multimodal contracts of carriage, applying a uniform regime. Everything would be predictable, with no gaps in the liability regime applicable from when the MTO takes charge of the goods to when the MTO delivers them. A limitation figure would have to be agreed, and here there would be the problem of choosing from the highest common denominator in the unimodal conventions - 19 SDR per kg under the Montreal Convention - or the lowest common denominator - 2 SDR per kg or 666.67 SDR per package or unit under the Hague-Visby Rules, or $£ 100$ gold value under the Hague Rules. There would then be the troubling matter of the multimodal operation of the unimodal conventions. These would have to be amended so that their definition of contract of carriage was restricted to international carriage where the entirety of the contractual performance is through that particular mode. Assuming this could be achieved, there would then open up a recourse gap between the MTO and the actual carriers used by the MTO to perform the multimodal contract of carriage. This might be soluble contractually by providing for the higher limits of the multimodal convention to apply, but there is a problem with the two-way non-derogation provisions in $\mathrm{CMR}^{104}$ and CMNI. These would need to be amended as well.

Alternatively, one could aim for one single international carriage convention to rule them all - unimodal and multimodal. Every state that is a party to the unimodal conventions

\footnotetext{
${ }^{101}$ IATA Air Waybill, cl 4.

102 ibid cl 2.1: 'Carriage is subject to the rules relating to liability established by the Warsaw Convention or the Montreal Convention unless such carriage is not "international carriage" as defined by the applicable Conventions.'

${ }^{103}$ Some of these gaps are also present with regard to unimodal sea carriage. With sea carriage, there is the gap in the Hague Rules between the reception of the goods at the port in the carrier's warehouse and the start of loading operations, mirrored by the gap between discharge and delivery from the warehouse at the end of the voyage, and the question of the application of the Hague Rules during periods of storage pending transshipment. Progressive loss of cargo was in issue in The Starsin ( $\mathrm{n} 95$ ), in which the House of Lords found that a single cause of action in negligence arose when the cargo was first damaged.

${ }^{104}$ The problem is more acute with CMR, as Art 1(5) provides: 'The Contracting Parties agree not to vary any of the provisions of this Convention by special agreements between two or more of them, except to make it inapplicable to their frontier traffic or to authorize the use in transport operations entirely confined to their territory of consignment notes representing a title to the goods.'
} 
would need to denounce them when signing up to the new super convention; otherwise there would be the risk of convention clash. The applicable limitation for the new convention would also need to be addressed. Go high or go low? Agreement on this would be almost impossible. Sea carriers would not want the Montreal Convention limits, which would result in an almost tenfold increase; conversely, air cargo interests would be unimpressed by any lowering of those limits.

That leaves the network solution that has been adopted contractually through the UNCTAD/ ICC Rules and then the BIMCO forms - MULTIDOC and COMBICONBILL. This provides a basic liability regime, which would then defer to the unimodal conventions where applicable $e^{105}$ and also to mandatory national laws. Its liability system would, therefore, cover only unlocalised loss and gaps between the unimodal conventions, subject to national mandatory law on those gaps. The Rotterdam Rules have adopted a limited network system, with Article 26 deferring to the unimodal conventions in cases of localised loss as regards liability, limitation of liability and time limits, and deferring to the multimodal provisions of the air, road, rail and inland waterways conventions in Article 82. Without wholesale denunciation of the unimodal conventions, the only scope for a multimodal convention would be as regards unlocalised loss or for localised loss falling outside the scope of any mandatory international convention or national law. The MTO's recourse for localised loss outside the scope of a mandatory international convention or national law would be subject to the terms of the MTO's contract with the actual carrier or service provider for that stage. There would be no recourse gap for unlocalised loss as, by definition, the MTO will not be able to be pin the loss or damage on any particular actual carrier. ${ }^{106}$

It would probably be feasible to secure agreement for a multimodal convention based on some form of presumed fault-based liability, with the Hague-Visby limits where carriage by sea or inland waterways is involved and the CMR limits where it is not, and with the unimodal conventions applying where the loss or damage is located within the scope of their operation. This looks very similar to what is already on offer through the two BIMCO forms - the only advantage of such a multimodal convention would be mandatory application. In any event, the advent of 'smart containers' ${ }^{107}$ means that the scope for unlocalised loss with containerised cargo will dwindle in future. Nor is there any compelling economic ground for renewing efforts to create a new international convention for multimodal carriage of goods. A 2001 report to the European Commission, The Economic Impact of Carrier Liability on Intermodal Freight Transport, estimated the total friction cost in Europe of carrier liability for existing intermodal transport operations ${ }^{108}$ at about $€ 500-550$ million per annum. ${ }^{109}$ However, harmonisation of conditions to facilitate intermodal transport - such as a uniform liability limit for all modes - could yield

\footnotetext{
${ }^{105}$ In some cases, as with the UNCTAD/ICC Rules and the MULTIDOC form, this deference appears to operate only as regards the limitation provisions of mandatory international conventions and national laws, but this is illusory, due to the effect of UNCTAD/ICC, r 13.

${ }^{106}$ In case of unlocalised loss, the MTO would incur liability as it would be unable to show how the loss occurred and would therefore not be able to show that the loss came within one of the applicable exceptions. For the same reason, it would be unable to claim recourse from any of its subcontractors.

${ }^{107}$ Through an equivalent of an aircraft 'black box' attached to the container, information can be captured in real time via a wide range of sensors about their current status (eg GPS position, door opening detection, movements vibrations and shocks, atmospheric conditions). The technology can be used to enable remote changing of container parameter settings (eg temperature setups, remote defrost) anywhere, anytime. See F Stevens, 'Smart Containers: The Smarter, the More Scope for Liability?' in B Soyer and A Tettenborn (eds), Maritime Liabilities in a Global and Regional Context (Abingdon, Informa Law, 2018) ch 5.

${ }^{108}$ These costs were estimated to amount to less than $0.2 \%$ of consignment (cargo) value, varying for different types of journey, depending particularly on consignment value and journey length. The level of risk for national, intra-Europe and extra-European carriage was estimated as amounting to $6.3 \%, 3.9 \%$ and $2.4 \%$ of the freight charges, respectively.

${ }^{109}$ This comes to about $€ 1$ per annum (the 2001 cost of a cup of coffee) for each man, woman and child in the EU.
} 
savings in friction costs to intermodal transport of a much lower figure of $€ 50$ million per annum. This is getting very close to de minimis. The EU figures indicate that the economic benefits of a global unified liability system are really not worth the candle; they may be offset by the costs of adjusting to a new regime while still applying the old system; and, as noted by Nikaki, a purely multimodal convention might well lead to a rise in freight rates by multimodal carriers to take account of the recourse gap. ${ }^{110}$

To answer the question posed in the title of this chapter: no, it is not time for a new convention. Far better to leave it to industry contract forms to sort out. 
